\title{
Ex vivo Cutaneous Bioavailability of Topical Mometasone Furoate in an O/W Preparation
}

\author{
Johannes Wohlraba,b Reinhard H.H. Neubert ${ }^{b, c}$ Elfi Sommer ${ }^{b} \quad$ Julia Michael ${ }^{b}$ \\ ${ }^{a}$ Department of Dermatology and Venereology, ${ }^{b}$ Institute of Applied Dermatopharmacy, and ${ }^{c}$ Institute of \\ Pharmacy, Martin Luther University Halle-Wittenberg, Halle (Saale), Germany
}

\section{Keywords}

Mometasone furoate $\cdot$ Drug delivery $\cdot$ Cutaneous

bioavailability $\cdot$ Penetration $\cdot$ Scratch assay

\begin{abstract}
Mometasone furoate (MMF) is a modern glucocorticoid of the 4th generation, which has been proven not only for inhalation but also for cutaneous treatment. Due to its lipophilic character, it is mainly used in ointments and creams with an outer lipophilic phase (W/O type). However, this study investigated the cutaneous cytotoxicology of MMF and tried to characterize its pharmacokinetic effects on the skin using an O/W preparation. An HPLC method has been developed and validated for the detection of MMF in cutaneous tissue, and concentration-time curves of MMF were created after cutaneous application on unaffected as well as lesional skin. Cytotoxicological characterization was carried out using scratch assays on keratinocytes and cutaneous fibroblasts. Results showed that the condition of the skin had no significant impact on the cutaneous bioavailability of MMF, but the intrinsic effect of the $\mathrm{O} / \mathrm{W}$ vehicle could be utilized in periods of acute inflammation. Cytotoxicological data gave no new indications regarding the safety of MMF.
\end{abstract}

(c) 2016 S. Karger AG, Basel (c) 2016 S. Karger AG, Basel

$1660-5527 / 16 / 0295-0273 \$ 39.50 / 0$

\section{Introduction}

Mometasone furoate (MMF) is a synthetic halogenated monoester of prednisolone with high lipophilicity (octanol water partition coefficient $\left[K_{\mathrm{OW}}\right]$ of 2,150$)$ and a high benefit-risk ratio [1-3]. Originally used as an inhaled glucocorticoid for respiratory diseases, subsequently MMF has also been used in lipophilic vehicles for epicutaneous application to treat inflammatory skin diseases [4-10]. MMF is freely soluble in acetone and methylene chloride, slightly soluble in ethanol, but practically insoluble in water. The drug is degraded into 6 - $\beta$-hydroxymometasone by cytochrome $\mathrm{P}_{450} 3 \mathrm{~A} 4[11,12]$. Its pharmacokinetic properties are comparable with other glucocorticoids [8, 13-17]. MMF is classified by Niedner [18, 19] as a highly potent glucocorticoid (class III out of IV). The duration of application and the galenic properties of the vehicle have a major influence on the therapeutic effect [20-23]. The efficacy of MMF as a topical treatment has been proven for a variety of inflammatory dermatoses [24-40]. Based on data from dose-finding studies, MMF for topical application is used in semisolid preparations in a concentration of $0.1 \%$ [41].

In order to make better use of the intrinsic effect of the vehicle, especially in periods of acute inflammation, an

\section{KARGER}

E-Mail karger@karger.com

www.karger.com/spp
Johannes Wohlrab, MD

Department of Dermatology and Venereology

Martin Luther University Halle-Wittenberg

Ernst-Grube-Strasse 40, DE-06097 Halle (Saale) (Germany)

E-Mail johannes.wohlrab @ medizin.uni-halle.de 
Table 1. Processing of the cutaneous layers and additional samples

\begin{tabular}{llll}
\hline Compartment & Sample & Section scheme & Extraction volume \\
\hline Nonpermeated fraction & Swab & & $2.0 \mathrm{~mL}$ \\
\hline Skin sections & Stratum corneum (SC) & $10 \mu \mathrm{m}$ & $0.1 \mathrm{~mL}^{\mathrm{a}}$ \\
& Vital epidermis (EP) & 4 sections à $20 \mu \mathrm{m}$ & $0.1 \mathrm{~mL}^{\mathrm{a}} / 0.4 \mathrm{~mL}^{\mathrm{b}}$ \\
& Dermis 1 (DR 1) & 5 sections à $40 \mu \mathrm{m}$ & $0.1 \mathrm{~mL}$ \\
& Dermis 2 (DR 2) & 5 sections à $40 \mu \mathrm{m}$ & $0.1 \mathrm{~mL}$ \\
& Dermis 3 (DR 3) & 5 sections à $40 \mu \mathrm{m}$ & $0.1 \mathrm{~mL}$ \\
& Dermis 4 (DR 4) & 5 sections à $40 \mu \mathrm{m}$ & $0.1 \mathrm{~mL}$ \\
& Dermis 5 (DR 5) & 5 sections à $40 \mu \mathrm{m}$ & $0.1 \mathrm{~mL}$ \\
& Remaining stump & & $0.1 \mathrm{~mL} / 0.2 \mathrm{~mL}^{\mathrm{b}}$ \\
\hline Permeated fraction & Filter gauze & & $2.0 \mathrm{~mL}$ \\
& Acceptor fluid & & $-/-$ \\
\hline
\end{tabular}

${ }^{\mathrm{a}}$ Intact skin. ${ }^{\mathrm{b}}$ Lesional skin.

MMF-containing $\mathrm{O} / \mathrm{W}$ vehicle has recently been created, whose efficacy can be compared to conventional W/O cream or ointment preparations $[21,24]$. With regard to a continuous long-term application especially on damaged skin, the concentration-time profile of MMF in the different skin layers is of vital importance not only for its therapeutic effect but also for the severity of its adverse reactions. Apart from the classical group effects within the genomic and nongenomic effects of glucocorticoids, direct substance-specific metabolic and cytotoxic effects have to be considered, which can affect mainly keratinocytes (epithelial atrophy) and fibroblasts (inhibition of collagen synthesis) as the main cell types in the respective target compartments [42, 43].

The aims of this study were to validate penetration profiles of the new galenic MMF preparation into intact as well as damaged skin and to prove its safety regarding the cytotoxicological effects of relevant MMF concentrations.

\section{Materials and Methods}

\section{Analytic Method}

An analytic HPLC-UV method for the quantification of MMF in skin was developed using an Agilent 1200 HPLC system (Agilent, Waldbronn, Germany) and validated according to FDA guidelines concerning selectivity, reproducibility, precision, and accuracy [44]. All samples were calculated using the method of external standard and weighted with $1 / \mathrm{C}^{2}$. MMF was determined using a ReproSil $100 \mathrm{C} 18,5 \mu \mathrm{m}, 125 \times 4 \mathrm{~mm}$ (Wicom, Heppenheim, Germany) with precolumn RP 18 EC 3/4 (Macherey-Nagel, Düren, Germany), a flow of $0.8 \mathrm{~mL} \mathrm{~min}^{-1}$ acetonitrile/water $(80 / 20$
$\mathrm{V} / \mathrm{V})+0.1 \%$ formic acid, $30^{\circ} \mathrm{C}$ column temperature, and $15 \mu \mathrm{L}$ injection volume. The detection was carried out by UV $(240 \mathrm{~nm})$. The method had a limit of determination of $0.064 \mu \mathrm{g} / \mathrm{mL}$ and a limit of detection of $0.005 \mu \mathrm{g} / \mathrm{mL}$.

\section{Sample Preparation}

Sections from the same skin compartment (Table 1) were stored together at $-20^{\circ} \mathrm{C}$ until processing and measuring. Swabs, which were used to absorb excess MMF, and filter gauzes were stored in 15 - $\mathrm{mL}$ test tubes. Acetonitrile/water 80/20 (v/v) was added for extraction (Table 1), and the test tubes moved for $24 \mathrm{~h}$ on a laboratory shaker. Skin samples were afterwards centrifuged at 13,000 rpm for $10 \mathrm{~min}$, and the supernatants were analyzed. One milliliter of the acceptor liquid from all cells, respectively, was evaporated under nitrogen atmosphere at $40^{\circ} \mathrm{C}$ and resolved with $0.5 \mathrm{~mL}$ acetonitrile/ water 80/20 (v/v). The concentrated samples were measured. Extracts of the swabs were diluted (1:10). For safeguarding, quality controls with known concentrations were carried out in parallel.

Test Preparation

A hydrophilic cream (O/W type) containing 0.1\% $\mathrm{MMF}$ (Monovo ${ }^{\circledR} ; 1$ mg/g creme; Almirall Hermal GmbH, Reinbek, Germany) was used.

\section{Diffusion Tests}

The tests were performed on excised human skin from reduction mammoplasty after proof of functional integrity as described previously [45] using a glass Franz diffusion cell (Crown Glass Company, Somerville, NJ, USA). Skin specimens of 3 donors each with 3 pieces of skin per setting and for each application period of 30, 100 and 300 min were investigated. For a second test series, the stratum corneum was manipulated with 10-fold stripping (Tesa ${ }^{\circledR}$; Beiersdorf, Hamburg, Germany; size: $15 \times 20 \mathrm{~mm}$ ) before testing in order to simulate a barrier defect (lesional skin). To determine the amount of penetrated MMF for the respective application periods, the skin samples were removed from the diffusion cell and the residues of the preparation were carefully removed from the 
surface using a cotton swab. In order to determine the concentration-time profile, the individual skin layers were horizontally separated using a cryomicrotome (stratum corneum: 1 section at 10 $\mu \mathrm{m}$ in intact skin experiments; vital epidermis: 4 sections at $20 \mu \mathrm{m}$; corium: 25 sections at $40 \mu \mathrm{m}+$ remaining stump). Demineralized water was used as acceptor. All samples were stored at $-40^{\circ} \mathrm{C}$ until analysis.

\section{Isolation, Cultivation, and Characterization of Native Cells from Human Skin}

Keratinocytes and fibroblasts were isolated and cultivated from human foreskin according to standardized protocols. After treatment with dispase, native keratinocytes were isolated from the preisolated epidermis as well as cutaneous fibroblasts from the dermis $[46,47]$. The cells were cultivated in 24 -well microtiter plates (Greiner) at $37^{\circ} \mathrm{C}, 20 \% \mathrm{CO}_{2}$, and $80 \%$ humidity until they reached a degree of confluency of 85\% [47]. After cultivation, the cells were harvested using a cell harvester (Inotech, Wohlen, Switzerland) and kept in standardized aliquots.

\section{Scratch Assay}

Native cutaneous keratinocytes and fibroblasts of the 2nd passage were coated with laminin/fibronectin/collagen IV (4:50:1, $\mathrm{v}: \mathrm{v}: \mathrm{v})$ in PBS $(27.5: 72.5, \mathrm{v}: \mathrm{v})$, then seeded on 6 -well plates $(0.2 \times$ $10^{6}$ cells/well in $4 \mathrm{~mL}$ ), and cultivated under the above-described conditions for $72 \mathrm{~h}$ until full confluency was reached [48]. For the simulation of a defect, a straight scratch was applied on the cell layer of each well using a sterile pipette tip. Subsequently, the cell debris was removed with pipettes, and a washing procedure with serum-free medium was carried out. DMSO (solvent control) and 0 (zero control), 0.5, 5.0, 50.0, and $100.0 \mu \mathrm{mol} / \mathrm{L}$ MMF were added to the cultures, then incubated for $48 \mathrm{~h}$, and photographed at 0,2 , $4,8,12,24$, and $48 \mathrm{~h}$. In the next step, image analysis was carried out [49].

As a measure for the migration rate, the percentage removal of the lesional area was compared to the initial value using the following formula:

$$
\text { scratch closure rate }=\left[\frac{(A t 0-A t x)}{A t 0}\right] \times 100 .
$$

where $A t 0=$ lesional area $\left(\mathrm{cm}^{2}\right)$ at time 0 and $A t x=$ lesional area $\left(\mathrm{cm}^{2}\right)$ at time $x$.

Three independent tests were carried out for each cell type and each experimental setting, and mean values were calculated.

\section{Digital Image Analysis}

The photographed microscopic images were analyzed with respect to the size of the lesions over time. For this purpose, the margins of the cell layers were marked as measuring lines, and the lesional area was quantified with the calibrated number of pixels (Image ${ }^{\circledR}, \mathrm{V} 1.49 \mathrm{~m}$; National Institutes of Health, Bethesda, MD, USA). The values for these areas were compared with the corresponding initial value, and a scratch closure rate was calculated, serving as a measure for the cytological integrity of the respective cell type.

\section{Biometric Evaluation}

Biometric evaluation was carried out using the statistics software XLStat V2014.5.02 (Addinsoft, New York, NY, USA). The descriptive statistics are based on the results of the independent individual experiments. The comparison of the independent random samples was carried out after the assessment of normal distribution and variance homogeneity using the one-way ANOVA model, the Student-Newman-Keuls method, the Holm-Bonferroni method, and the Kruskal-Wallis test. Differences between test and control results were assumed to be statistically significant at an error probability of $\mathrm{p}<0.05$.

\section{Results}

\section{Penetration Tests}

The concentration-time profiles from the diffusion tests with MMF on unaffected and damaged skin showed no relevant differences regarding the cutaneous bioavailability in the target compartments vital epidermis and dermis (Fig. 1). Nevertheless, a considerable reservoir was detected in the stratum corneum of intact skin. However, it had no pharmacokinetic relevance within the time frame up to $300 \mathrm{~min}$. After $30 \mathrm{~min}$, a relevant surplus in concentration could be found only in the vital epidermis of damaged skin, which was compensated after $300 \mathrm{~min}$. Within the acceptor of both unaffected and damaged skin, the concentrations were below the detection limit. The mean concentration ranges of $\mathrm{MMF}$ within the target compartments vital epidermis (50-100 $\mu \mathrm{mol} / \mathrm{L})$ and corium (5-25 $\mu \mathrm{mol} / \mathrm{L}$ ) were used as a basis for the concentration range used in the cytotoxicological test (scratch assay).

\section{Scratch Assay}

The results from the scratch assay for cytotoxicology showed no concentration-depending or other relevant MMF-specific effects on keratinocytes or fibroblasts (Fig. 2). This also applies for the intrinsic effect of the solubilizing agent DMSO. However, regardless of the concentration, dispersion was greater for keratinocytes than for fibroblasts, which is especially apparent after $48 \mathrm{~h}$. The level and time of the closure rate is comparable in both cell types.

\section{Discussion}

The present results for the pharmacokinetics of MMF correspond to the known characteristics of topically applied glucocorticoids [50]. The special feature here is the use of an $\mathrm{O} / \mathrm{W}$ galenic preparation, which on the one hand suggests an improved release of the lipophilic MMF; on the other hand, however, no improved penetration into or permeation through the vital skin layers compared to an W/O preparation can be expected. This is as- 


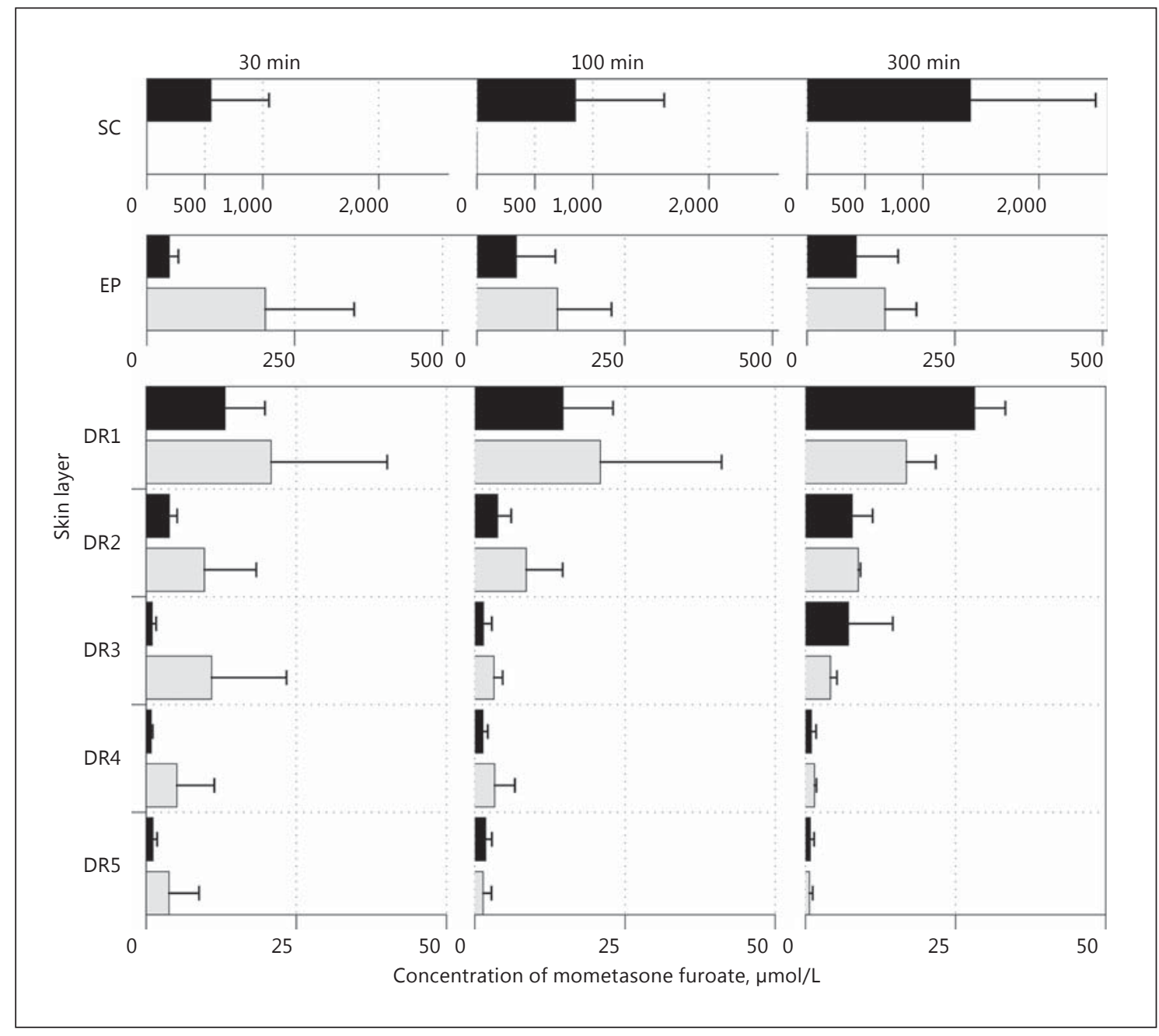

Fig. 1. Concentration profiles of mometasone furoate in comparison to intact and lesional skin and different application times $(30,100$, and $300 \mathrm{~min})$. Means and SD. SC, stratum corneum; EP, vital epidermis; DR, dermis; black bars, intact skin; gray bars, lesional skin.

sumed because the acceptor is very hydrophilic especially in acutely inflamed skin. Unfortunately, there are no pharmacokinetic data for a W/O preparation with the same active substance available, and, therefore, no direct comparisons regarding cutaneous bioavailability can be drawn. Clinical data, however, clearly show the therapeutic equivalence of both galenic systems [24]. Moreover, especially in inflamed skin, the use of an $\mathrm{O} / \mathrm{W}$ vehicle is by all means advantageous from a clinical point of view (e.g. nonocclusive) as well as from the patients' perspective (e.g. nongreasy) [51]. The outer continuous aqueous phase causes evaporation chill, which has again a vasoconstrictive and therefore anti-inflammatory effect. Also, the occlusive intrinsic effect is considerably reduced com- pared to a W/O preparation. However, with regard to the anti-inflammatory therapy of psoriasis, this effect can even be unfavorable especially when treating hyperkeratotic plaques. This is a known key argument for combined topical therapy of glucocorticoids with keratolytics (such as salicylic acid) for the initial treatment.

Comparing intact and lesional skin, the diffusion tests showed no relevant differences in pharmacokinetics especially regarding the cutaneous bioavailability in the target compartments vital epidermis and dermis. Although a considerable MMF reservoir in the stratum corneum of intact skin was observed, no influence on the diffusion kinetics into deeper layers could be determined within the investigated time frame of up to $300 \mathrm{~min}$. On the one 

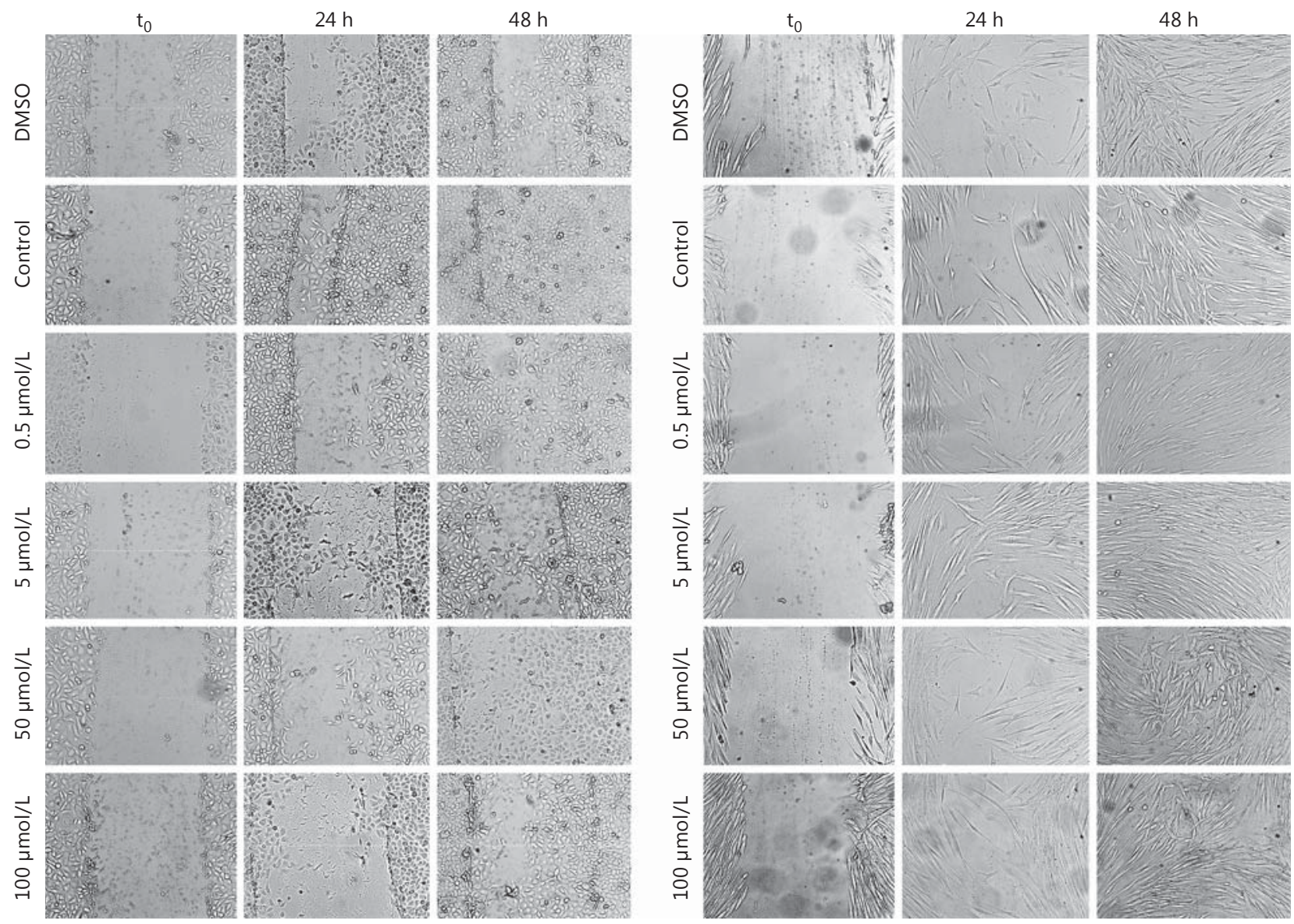

a

\section{b}
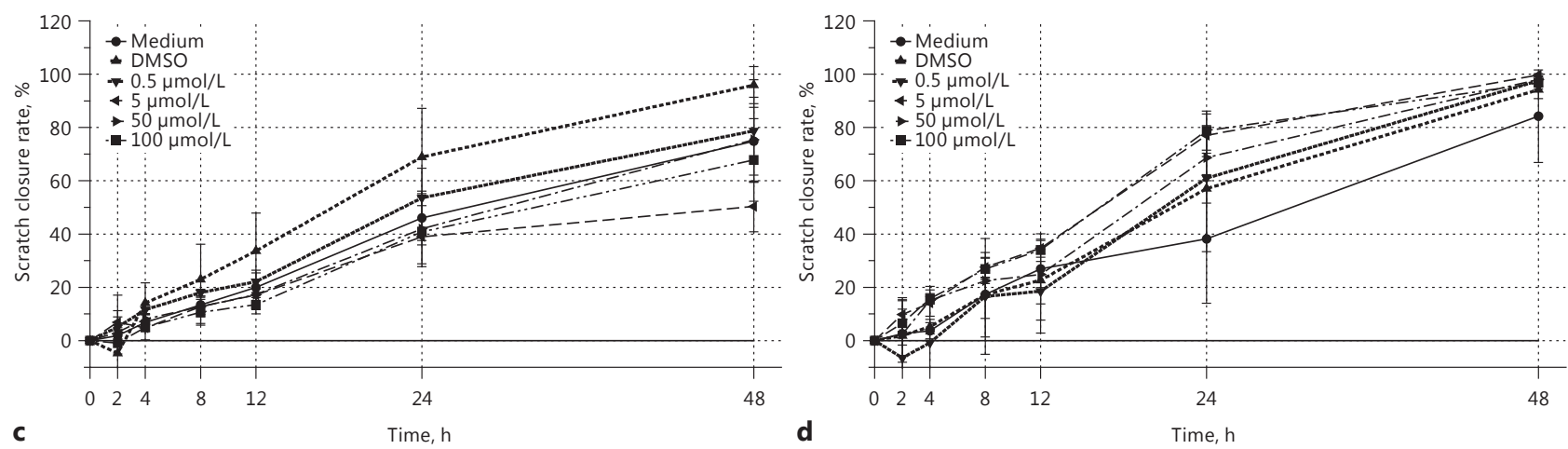

Fig. 2. Photographic documentation (a, b) of dose-dependent scratch closure status at baseline, and 24 and $48 \mathrm{~h}$ after application of the test substance, and results of image analysis $(\mathbf{c}, \mathbf{d})$ of scratch closure rate at baseline, and $2,4,8,12,24$, and $48 \mathrm{~h}$ after adding the test substance to keratinocyte (a, c) and fibroblast cultures (b, d). 
hand, this corroborates the clinical data for therapeutic equivalence; on the other hand, no indications for a change in the safety profile are given. This includes both, the range of concentration-dependent adverse cutaneous effects as well as the potential systemic bioavailability [52]. The detectable concentrations of MMF in the vital epidermis (about $100 \mu \mathrm{mol} / \mathrm{L}$ ) and in the dermis (about $20 \mu \mathrm{mol} / \mathrm{L}$ ) were within a cutaneous toxicologically harmless dose range [21]. However, the current evidence for cutaneous toxicological effects is quite low, and whether the toxicological data from MMF inhalation can be directly transferred remains doubtful. Therefore, cytotoxicological data for keratinocytes and fibroblasts from the scratch test were collected. The results give no indication for relevant substance-specific effects. Thus, no relevant clinical symptoms caused by adverse cutaneous effects are to be expected, at least for short- and medium-term use. This was also proven by the currently available safety data from clinical studies $[21,24]$.

In conclusion, the use of an $\mathrm{O} / \mathrm{W}$ galenic preparation for epicutaneous application of MMF is advantageous because of the intrinsic effects of the vehicle especially in periods of acute inflammation. Regarding intact and damaged skin, pharmacokinetic equivalence was proven.

\section{Acknowledgments}

The authors wish to thank Mrs. Claudia Bruhne, Mrs. Sylke Fasshauer, Mrs. Anke Nies, and Dr. Yahya Mrestani for excellent technical assistance.

\section{Statement of Ethics}

All experiments were carried out in accordance with the guidelines of, and approved by, the ethics committee of the medical faculty of the Martin Luther University Halle-Wittenberg.

\section{Disclosure Statement}

The study was partially sponsored by Almirall Hermal GmbH, Reinbek, Germany. J.W. has received fees for lecturing and/or consulting, and/or received funding for scientific projects and/or clinical studies from Abbott, Abbvie, Agfa, Aicuris, Almirall, Amgen, Astellas, Biogen-Idec, Bombastus, Dermapharm, Ei, Evolva, Evonik, Galderma, Grünenthal, GSK, Intendis, JanssenCilag, Jenapharm, Leo, L'Oréal, Mavena, Mibe, MSD, Novaliq, Novartis, Pfizer, Reddys, Riemser, Skinomics, Spirig, Stiefel, Widmer, and Wolff. R.H.H.N, E.S., and J.M. declare no conflict of interest.

\section{References}

1 Schafer-Korting M, Schmid MH, Korting HC: Topical glucocorticoids with improved risk-benefit ratio. Rationale of a new concept. Drug Saf 1996;14:375-385.

2 Luger T, Loske KD, Elsner P, Kapp A, Kerscher M, Korting HC, Krutmann J, Niedner R, Rocken M, Ruzicka T, Schwarz T: Topical skin therapy with glucocorticoids - therapeutic index (in German). J Dtsch Dermatol Ges 2004;2:629-634.

3 Korting HC, Kerscher MJ, Schafer-Korting M: Topical glucocorticoids with improved benefit/risk ratio: do they exist? J Am Acad Dermatol 1992;27:87-92.

4 Derendorf H, Daley-Yates PT, Pierre LN, Efthimiou J: Bioavailability and metabolism of mometasone furoate: pharmacology versus methodology. J Clin Pharmacol 2002;42:383-387.

5 Crim C, Pierre LN, Daley-Yates PT: A review of the pharmacology and pharmacokinetics of inhaled fluticasone propionate and mometasone furoate. Clin Ther 2001;23:1339-1354.

6 Tayab ZR, Fardon TC, Lee DK, Haggart K, McFarlane LC, Lipworth BJ, Hochhaus G: Pharmacokinetic/pharmacodynamic evaluation of urinary cortisol suppression after inhalation of fluticasone propionate and mometasone furoate. Br J Clin Pharmacol 2007; 64:698-705.
7 Hoffmann K, Auer T, Stucker M, Hoffmann A, Altmeyer P: Comparison of skin atrophy and vasoconstriction due to mometasone furoate, methylprednisolone and hydrocortisone. J Eur Acad Dermatol Venereol 1998;10: 137-142.

8 Koivukangas V, Karvonen J, Risteli J, Oikarinen A: Topical mometasone furoate and betamethasone-17-valerate decrease collagen synthesis to a similar extent in human skin in vivo. Br J Dermatol 1995;132:66-68.

9 Isogai M, Shimizu H, Esumi Y, Terasawa T, Okada T, Sugeno K: Binding affinities of mometasone furoate and related compounds including its metabolites for the glucocorticoid receptor of rat skin tissue. J Steroid Biochem Mol Biol 1993;44:141-145.

10 Singh SK, Tehseen M, Kalam A: Mometasone furoate is a safe topical corticosteroid? Indian J Dermatol Venereol Leprol 2000;66:275.

11 Kubota K, Ademola J, Maibach HI: Metabolism of topical drugs within the skin, in particular glucocorticoids. Curr Probl Dermatol 1993;21:61-66.

12 Teng XW, Cutler DJ, Davies NM: Mometasone furoate degradation and metabolism in human biological fluids and tissues. Biopharm Drug Dispos 2003;24:321-333.
13 Ahluwalia A: Topical glucocorticoids and the skin - mechanisms of action: an update. Mediators Inflamm 1998;7:183-193.

14 Mills CM, Marks R: Side effects of topical glucocorticoids. Curr Probl Dermatol 1993;21: 122-131.

15 Taheri A, Cantrell J, Feldman SR: Tachyphylaxis to topical glucocorticoids; what is the evidence? Dermatol Online J 2013;19:18954.

16 Curnow SJ, Wloka K, Faint JM, Amft N, Cheung CM, Savant V, Lord J, Akbar AN, Buckley CD, Murray PI, Salmon M: Topical glucocorticoid therapy directly induces upregulation of functional CXCR4 on primed T lymphocytes in the aqueous humor of patients with uveitis. J Immunol 2004;172:7154-7161.

17 Valotis A, Neukam K, Elert O, Hogger P: Human receptor kinetics, tissue binding affinity, and stability of mometasone furoate. J Pharm Sci 2004;93:1337-1350.

18 Niedner R: Classification of external corticoids (in German). ZFA (Stuttgart) 1983;59: 367-369.

19 Niedner R: Glukokortikosteroide in der Dermatologie. Dtsch Ärztebl 1996;93:2868-2872.

20 Stoughton RB, Wullich K: Relation of application time to bioactivity of a potent topical glucocorticoid formulation. J Am Acad Dermatol 1990;22:1038-1041. 
21 Raposo S, Tavares R, Goncalves L, Simoes S, Urbano M, Ribeiro HM: Mometasone furoate-loaded cold processed oil-in-water emulsions: in vitro and in vivo studies. Drug Deliv 2015;22:562-572.

22 Greive KA, Barnes TM: Bioequivalence of $0.1 \%$ mometasone furoate lotion to $0.1 \%$ mometasone furoate hydrogel. Australas J Dermatol 2016;57:e39-e45.

23 FDA: Guidance for Industry: Topical Dermatologic Corticosteroids: In vivo Bioequivalence. Silver Spring, Center for Drug Evaluation, Food, and Drug Administration, 1995.

24 Korting HC, Schollmann C, Willers C, Wigger-Alberti W: Bioavailability, antipsoriatic efficacy and tolerability of a new light cream with mometasone furoate $0.1 \%$. Skin Pharmacol Physiol 2012;25:133-141.

25 Katsarou A, Makris M, Papagiannaki K, Lagogianni E, Tagka A, Kalogeromitros D: Tacrolimus $0.1 \%$ vs mometasone furoate topical treatment in allergic contact hand eczema: a prospective randomized clinical study. Eur J Dermatol 2012;22:192-196.

26 Miller RC, Schwartz DJ, Sloan JA, Griffin PC, Deming RL, Anders JC, Stoffel TJ, Haselow RE, Schaefer PL, Bearden JD 3rd, Atherton PJ, Loprinzi CL, Martenson JA: Mometasone furoate effect on acute skin toxicity in breast cancer patients receiving radiotherapy: a phase III double-blind, randomized trial from the North Central Cancer Treatment Group N06C4. Int J Radiat Oncol Biol Phys 2011;79: 1460-1466.

27 Khope S: Topical mometasone furoate for phimosis. Indian Pediatr 2010;47:282.

28 Tiplica GS, Salavastru CM: Mometasone furoate $0.1 \%$ and salicylic acid $5 \%$ vs mometasone furoate $0.1 \%$ as sequential local therapy in psoriasis vulgaris. J Eur Acad Dermatol Venereol 2009;23:905-912.

29 Stinco G, Lautieri S, Piccirillo F, Valent F, Patrone P: Response of cutaneous microcirculation to treatment with mometasone furoate in patients with psoriasis. Clin Exp Dermatol 2009;34:915-919.

30 Pileggi Fde O, Vicente YA: Phimotic ring topical corticoid cream $(0.1 \%$ mometasone furoate) treatment in children. J Pediatr Surg 2007;42:1749-1752.

31 Aguirre JM, Bagan JV, Rodriguez C, Jimenez Y, Martinez-Conde R, Diaz de Rojas F, Ponte A: Efficacy of mometasone furoate microemulsion in the treatment of erosive-ulcerative oral lichen planus: pilot study. J Oral Pathol Med 2004;33:381-385.
32 Cattaneo A, De Magnis A, Botti E, Sonni L, Carli P, Taddei GL: Topical mometasone furoate for vulvar lichen sclerosus. J Reprod Med 2003;48:444-448.

33 Alomar A, Puig L, Gallardo CM, Valenzuela $\mathrm{N}$ : Topical tacrolimus $0.1 \%$ ointment (protopic) reverses nickel contact dermatitis elicited by allergen challenge to a similar degree to mometasone furoate $0.1 \%$ with greater suppression of late erythema. Contact Dermatitis 2003;49:185-188.

34 Schnopp C, Remling R, Mohrenschlager M, Weigl L, Ring J, Abeck D: Topical tacrolimus (FK506) and mometasone furoate in treatment of dyshidrotic palmar eczema: a randomized, observer-blinded trial. J Am Acad Dermatol 2002;46:73-77.

35 Chunharas A, Wisuthsarewong W, Wananukul S, Viravan S: Therapeutic efficacy and safety of loratadine syrup in childhood atopic dermatitis treated with mometasone furoate 0.1 per cent cream. J Med Assoc Thai 2002;85: 482-487.

36 Faergemann J, Christensen O, Sjovall P, Johnsson A, Hersle K, Nordin P, Edmar B, Svensson A: An open study of efficacy and safety of long-term treatment with mometasone furoate fatty cream in the treatment of adult patients with atopic dermatitis. J Eur Acad Dermatol Venereol 2000;14:393-396

37 Teixeira F, Mosqueda-Taylor A, Montano S, Dominguez-Soto L: Treatment of recurrent oral ulcers with mometasone furoate lotion. Postgrad Med J 1999;75:574.

38 Masuria BL, Batra A, Kothiwala RK, Khuller R, Singhi MK: Topical mometasone furoate for the treatment of childhood vitiligo. Indian J Dermatol Venereol Leprol 1999;65:219221.

39 Viglioglia P, Jones ML, Peets EA: Once-daily $0.1 \%$ mometasone furoate cream versus twice-daily $0.1 \%$ betamethasone valerate cream in the treatment of a variety of dermatoses. J Int Med Res 1990;18:460-467.

40 Katz HI, Prawer SE, Watson MJ, Scull TA, Peets EA: Mometasone furoate ointment $0.1 \%$ vs. hydrocortisone ointment $1.0 \%$ in psoriasis. Atrophogenic potential. Int J Dermatol 1989;28:342-344.

41 Medansky RS, Bressinck R, Cole GW, Deeken $\mathrm{JH}$, Ellis CN, Guin JD, Herndon JH, Lasser AE, Leibsohn E, Menter MA, et al: Mometasone furoate ointment and cream 0.1 percent in treatment of psoriasis: comparison with ointment and cream formulations of fluocinolone acetonide 0.025 percent and triamcinolone acetonide 0.1 percent. Cutis 1988;42: 480-485.
42 Wach F, Bosserhoff A, Kurzidym U, Nowok K, Landthaler M, Hein R: Effects of mometasone furoate on human keratinocytes and fibroblasts in vitro. Skin Pharmacol Appl Skin Physiol 1998;11:43-51.

43 Korting HC, Hulsebus E, Kerscher M, Greber $\mathrm{R}$, Schafer-Korting M: Discrimination of the toxic potential of chemically differing topical glucocorticoids using a neutral red release assay with human keratinocytes and fibroblasts. Br J Dermatol 1995;133:54-59.

44 US Department of Health and Human Services, Food and Drug Administration: Guidance for Industry - Bioanalytical Method Validation. Silver Spring, Center for Drug Evaluation, Food, and Drug Administration, 2001.

45 Wohlrab J, Neubert RH, Heskamp ML, Michael J: Cutaneous drug delivery of capsaicin after in vitro administration of the $8 \%$ capsaicin dermal patch system. Skin Pharmacol Physiol 2015;28:65-74.

46 Normand J, Karasek MA: A method for the isolation and serial propagation of keratinocytes, endothelial cells, and fibroblasts from a single punch biopsy of human skin. In Vitro Cell Dev Biol Anim 1995;31:447-455.

47 Daniels JT, Kearney JN, Ingham E: Human keratinocyte isolation and cell culture: a survey of current practices in the UK. Burns 1996;22:35-39.

48 Cory G: Scratch-wound assay. Methods Mol Biol 2011;769:25-30.

49 Felice F, Zambito Y, Belardinelli E, Fabiano A, Santoni T, Di Stefano R: Effect of different chitosan derivatives on in vitro scratch wound assay: a comparative study. Int J Biol Macromol 2015;76:236-241.

50 Wiedersberg S, Leopold CS, Guy RH: Bioavailability and bioequivalence of topical glucocorticoids. Eur J Pharm Biopharm 2008;68: 453-466.

51 Wohlrab J, Richter C, Stauder S: Preclinical and clinical characterization of the cutaneous bioavailability of the hydrophilic phase of a water-in-oil emulsion. J Dtsch Dermatol Ges 2016;14:698-705.

52 Kerscher MJ, Hart H, Korting HC, Stalleicken D: In vivo assessment of the atrophogenic potency of mometasone furoate, a newly developed chlorinated potent topical glucocorticoid as compared to other topical glucocorticoids old and new. Int J Clin Pharmacol Ther 1995;33:187-189. 